IRA-International Journal of Management \& Social Sciences

ISSN 2455-2267; Vol.07, Issue 02 (2017)

Pg. no. 223-231

Institute of Research Advances

http://research-advances.org/index.php/RAJMSS

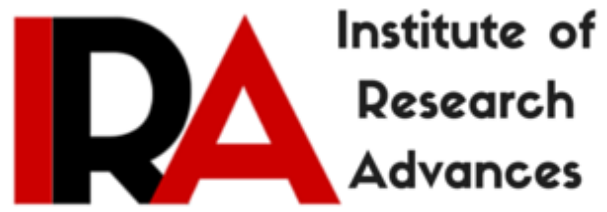

\title{
Productivity Change Trend Analysis of Thai Maize Production: An Application of Malmquist Productivity Index Approach
}

\author{
Bamrungphong Phongphanich ${ }^{\mathbf{1}}$ and Ke-Chung Peng ${ }^{\mathbf{2}}$ \\ ${ }^{1}$ Department of Tropical Agriculture and International Cooperation, International College, \\ National Pingtung University of Science and Technology, No.1, Shuefu Road, Neipu, \\ Pingtung 91201, Taiwan. \\ ${ }^{2}$ Departmentof Agribusiness Management, College of Management, National Pingtung \\ University of Science and Technology, No.1, Shuefu Road, Neipu, Pingtung 91201, \\ Taiwan.
}

Type of Review: Peer Reviewed.

DOI: http://dx.doi.org/10.21013/jmss.v7.n2.p12

\section{How to cite this paper:}

Phongphanich, B., \& Peng, K. (2017). Productivity Change Trend Analysis of Thai Maize Production: An Application of Malmquist Productivity Index Approach. IRA-International Journal of Management \& Social Sciences (ISSN 2455-2267), 7(2), 223-231. doi:http://dx.doi.org/10.21013/jmss.v7.n2.p12

(C) Institute of Research Advances

\section{(cc) EY-NC}

This work is licensed under a Creative Commons Attribution-Non Commercial 4.0 International License subject to proper citation to the publication source of the work.

Disclaimer: The scholarly papers as reviewed and published by the Institute of Research Advances (IRA) are the views and opinions of their respective authors and are not the views or opinions of the IRA. The IRA disclaims of any harm or loss caused due to the published content to any party. 


\begin{abstract}
The purpose of this study is to measure and analyze the productivity change of Thai maize production by using Malmquist productivity index (MPI) approach from the year 2008to 2015. The results analysis found that the maize productivity change in Thailand over study periods had the average productivity progression at $1.6 \%$ and its cause was the technical efficiency change and the technological change. However, some provinces still need to be improved the change of productivity. Furthermore, our findings indicated that the North had a productivity progression about $4.6 \%$. Meanwhile, the Northeast and Central revealed a productivity regression at 0.4 and $1.1 \%$, respectively. Based on the empirical finding, this study could provide important information for proposing policy implications which will be useful to the government, farmers, maize research institutes, and development partners for enhancing the sustainable maize productivity trend in some provinces of Thailand.
\end{abstract}

Keywords: Maize production; Malmquist productivity index; Productivity change; Technical efficiency change; Technological change; Thailand

\title{
Introduction
}

Maize is an important economic crop in Southeast Asia for being main raw material for animal feed industry. Thailand is the fourth largest maize producer in this region which production quantity in 2015 accounts for about 4,028,058 tons. Besides, the planted area and harvested area were 1,060,328 and 1,003,831 hectares, respectively and have increasing trends constantly [15]. Thailand is one of the leading maize exporters in Southeast Asia where the important export countries are Philippines, Malaysia, Indonesia, and Vietnam. Interestingly, maize production plays a crucial role in economic development of Thailand. Meanwhile, the most of maize growing area in 2015 are located in the North (69\%), followed by the Northeast (20\%) and the Central (11\%)[15].Consequently, maize production in each region of Thailand is also very different. The purpose of this study is to measure and analyze the productivity change trend of maize production in different region of Thailand during the year 2008 to 2015 by using Malmquist productivity index (MPI) approach.

According to the productivity theory, the definition is an essential relationship between outputs produced and inputs used in the production system[1,9, 14].This can be evaluated regarding level and rate changes; while, researchers are interested in the productivity change study due to it is more important to utilize the productivity measurement as index of the performance[14].Furthermore, an appropriate technique for the productivity change analysis of agricultural production, particularly maize production, the MPI approach has been used.However, few empirical studies have estimated the change of productivity in maize production by using MPI analysis because of the limitations of data used. Table 1 shows the previous studies on the productivity change of maize and other agricultural productions using the MPI analysis.

Therefore, as above literature review of MPI analysis has revealed that this distinctive technique is useful and suitable research method for analyzing the change of productivity over time period.

\section{Research Methodology}

\section{Malmquist Productivity Index (MPI) Approach}

Reference [12] and [17] proposed the concept of distance function; while, it is the beneficial foundation in explaining the technological method for measuring the efficiency and change of productivity[6].The MPI approach under based on the distance function was primarily initiated in two interesting research papers by $[2,3]$. The MPI has been interpreted as the measurement of the total factor productivity change (TFPC).The TFPC index can be further decomposed into two components as the technical efficiency change (TEC) and the technological change (TC). Hence, both indices can effectively specify the major source of productivity change trend. Moreover, the MPI approach applies panel data for computing the three indices between the time period $t$ and $t+1$ appropriately. Reference [7] suggested the distance function by the MPI based on constant returns to scale (CRS) 
model can productively estimate the productivity change of Decision Making Units (DMUs) over time period.

In this study, we employed the input-oriented MPI under CRS model for evaluating the productivity change of maize production in Thailand during the year 2008 to 2015.Thus, the MPI can be determined the equation as follows:

where $M_{i}$ is the input-oriented MPI. $D^{t}$ is the distance function in the time period $t$; as well as, $X^{t}$ and $y^{t}$ denote inputs and outputs in the time period $t . D^{t+1}$ is the distance function in the time period $t+1$; while, $X^{t+1}$ and $y^{t+1}$ depict inputs and outputs in the time period $t+1$. The input-oriented MPI can be actually expressed as the geometric mean.

If $M_{i}$ signifies a value equal to one, more than one and less than one when DMUs show a constant index of productivity, productivity growth and productivity decline between the time period $t$ and $t+1$.Besides, TEC is equal to one when technical efficiency of DMUs is unchanged, greater than one when technical efficiency of DMUs is increasing and less than one when technical efficiency of DMUs is decreasing from the time period $t$ and $t+1$. Subsequently, TC is equal to one, more than one and less than one if DMUs indicate no-change in technology, improving in technology and deteriorating in technology during the time period $t$ and $t+1$, respectively.

\section{Variables and Data analysis}

In this study, we used the secondary data in terms of provincial-level statistics which collected from surveying through various government organizations in Thailand, consisting of the Office of Agricultural Economics of Ministry of Agriculture and Cooperatives, and Royal Irrigation Department of Ministry of Agriculture and Cooperatives. The study used a panel data regarding to Thai maize production from the year 2008to 2015for measuring the change of productivity. The research area is located in three different regions, namely the North, Northeast and Central of Thailand, covering 39 provinces. This study analyzed one outputs produced, comprising quantity of maize and a total of five input used, namely planted area, seed, fertilizer, number of household, and irrigated land. Hence, the description of variables used in Thai maize production can be illustrated in Table 2. Data analysis for this study was conducted using the DEAP 2.1 program and STATA 12.Table 3 shows the descriptive statistics for variables used of maize production in Thailand during the year 2008to 2015. The findings indicated that on the mean, quantity of maize showed a very high number at 119,231.14 tons. Besides, the planted area was 29,426.21hectares; while, the seed was 598.10 tons, fertilizer was 9,768.77 tons, number of household was 10,862.18, and irrigated land had a very high number at $72,003.61$ hectares.

\section{Results and Discussion}

The findings obtained by the calculation of the TEC, the TCand the TFPCfor maize production in Thailand during the year 2008 to 2015 are presented in Table4. As above findings are estimated with the DEAP 2.1 software [4].

The average of TEC, TC and TFPC in Thai maize production showed the progression trend by 0.9 , 0.6 and 1.6\%; while, the main source of TFPC growth was the TEC and the TC. In turn, the average TEC showed the upward trend in the North, Northeast and Central by $1.0,0.7$, and $0.9 \%$, respectively. While, the mean TC rose by $3.6 \%$ for the North; whereas, the mean TC decline was found in the Northeast and Central at 1.1 and 2.0\%.In the mean TFPC growth of maize production performed at $4.6 \%$ for the North mainly due to the TEC and the TChave improved. On the other hand, the mean TFPC decrease was displayed in the Northeast and Central at 0.4 and $1.1 \%$ mainly because of the TC has not improved.

Among the total 39 provinces in three different regions of the country, ten provinces in the North, four provinces in the Northeast and seven provinces in the Central assessed the TEC growth; while, the positive growth of the TC could be determined in twelve provinces in the North, three province in the Northeast, and four provinces in the Central. In the TFPC results indicated that a large number of provinces in the North, totally fifteen provinces performed an overall improvement over ten-year 
periods which comprised Mae Hong Son (19.9\%), Nan (11.7\%), Uttaradit (10.1\%), Chiang Mai (8.3\%), Phetchabun (6.7\%), Phrae (5.3\%), Chiang Rai (4.5\%), Lampang (4.4\%), Tak (3.4\%), Phayao (2.3\%), Lamphun (2.1\%), Nakhon Sawan (1.0\%), Phitsanulok (0.5\%), Kamphaeng Phet (0.2\%), and Sukhothai $(0.1 \%)$. Subsequently, six provinces in the Northeast, namely Chaiyaphum, Nong Kai, Khon Kaen, Nakhon Ratchasima, Udon Thani and Sisaket had the TFPC gain of approximately 1.8, $1.6,1.3,0.9,0.5$, and $0.2 \%$, respectively. Moreover, six provinces in the Central presented the progression tendency of the TFPC which consisted of Phetchaburi (4.7\%), Chanthaburi(4.6\%), Prachin Buri (2.2\%), Lopburi (1.3\%), Kanchanaburi (0.7\%), and Ratchaburi (0.7\%), consecutively. Interestingly, six provinces in the North as Mae Hong Son, Uttaradit, Chiang Mai, ChiangRai, Lampang and Lamphun, three provinces in the Central named Phetchaburi, Chanthaburi and Prachin Buri had an improvement in the TEC, the TC, and the TFPC. Surprisingly, there was no any provinces in the Northeast performed an improvement in all above three indices. In turn, from the results of the index ranking indicated that in the North, Uttaradit experienced the best progression in the TEC; while, Mae Hong Son showed the highest improvement in the TC and the TFPC. In the Northeast, Khon Kaen presented the greatest gain in the TEC, Nong Kai revealed the most progress in the TC; as well as, Chaiyaphum had the largest improvement in the TFPC during the year 2008 to 2015. In the Central, Phetchaburi precisely displayed the highest growth in all three indices in the study period.Therefore, an overview of this study found that the majority provinces in three different regions of the country have showed the progression trend in the TFPC that is mainly caused by the increasing in the TEC and the TC.

\section{Conclusions}

Maize is a major agricultural crop in Thailand. Maize production plays an important role to develop economy of the country. This study measured and analyzed the productivity change trend of maize production in Thailand duringthe year 2008to 2015 by employing MPI technique. The research area contained 39 provinces among three different regions of the country. The Malmquist index results displayed that the average productivity change of whole country in Thai maize production improve at $1.6 \%$ annually over time period and the major source of increasing trend was the TEC and the TC. Nevertheless, some provinces still need to be improved the productivity change. Interestingly, the North had a progression trend in the TFPC about $4.6 \%$ that was mainly caused by the upward trends in the TEC and the TC. The Northeast found a downward tendency in TFPC at $0.4 \%$. The decreasing trend in this region was mainly due to the decline in the TC. Furthermore, the Central had a regression trend in the TFPC at $1.1 \%$ that was also mainly caused by the downward trend in the TC.

Based on the empirical observation, this study could provide important information for determining policy implications to develop Thai maize production. They should be enacted to support modern production technology, a compulsory education and advance technical training, research in agricultural production, especially maize farming, and infrastructure facilities. Consequently, as above policy implications will be beneficial to the government, farmers, maize research institutes, and development partners for increasing the sustainable performance and maize productivity trend in some provinces of Thailand.

\section{References}

[1]. Antle, M.J.,\&Capalbo, S.M. (1988).An introduction to recent development in production theory and productivity measurement. In Capalbo, S.M., \&Antle, M.J.Agricultural Productivity:

Measurement and Explanation.Washington DC: Resources for the Future, Inc.

[2]. Caves, D.W., Christensen, L.R., \& Diewert, W.E. (1982a).Multilateral comparisons of output, input, and productivity using superlative index numbers. Economic Journal92(365), 73-86.

[3]. Caves, D.W., Christensen, L.R., \&Diewert, W.E. (1982b). The economic theory of index numbers and the measurement of input, output, and productivity. Econometrica50(6), 1393-1414.

[4]. Coelli, T. (1996). A guide to DEAP version 2.1: A Data Envelopment Analysis (computer) program(CEPA working paper no.8). Armidale: University of New England.

[5]. Coelli, T., Perelman, S., \& Lierde, D.V. (2006). CAP reforms and total factor productivity growth on Belgian agriculture: A Malmquist index approach. Contributed Paper for Presentation at the $26^{\text {th }}$ 
Conference of the International Association of Agriculture Economists (IAAE), the Gold Coast, August 12-18.

[6]. Coelli, T.J., Rao, D.S.P., O’Donnell, C.J., \& Battese, G.E. (2005). An introduction to efficiency and productivity analysis. New York: Springer.

[7]. Färe R., Grosskopf, S., Norris, M., \&Zhang, Z. (1994). Productivity growth, technical progress, and efficiencychange in industrialized countries. American Economic Review84(1), 66-83.

[8]. Hassan, Y., Abdullah, A.M., Ismail, M.M.,\& Mohamed, Z.A. (2014). Factors influencing the total factor productivity growth of maize production in Nigeria. Journal of Agriculture and Veterinary Science7(4), 34-43.

[9]. Iyaniwura,O.,\& Osoba, A.M. (1983).Measuring productivity, conceptual, and statistical problems: improvement of statistics. In Osoba, A.M (Ed.),Productivity in Nigeria. Proceedings of a National Conference. Ibadan: NISER.

[10]. Latruffe, L., Fogarasi, J., \&Desjeux, Y. (2012). Efficiency, productivity, and technology comparison for farms in Central and Western Europe: The case of field crop and dairy farming in Hungary and France. Economic Systems36(2), 264-278.

doi: 10.1016/j.ecosys.2011.07.002.

[11]. Liu, S., Zhang, P., He, X., \&Li, J. (2015). Efficiency change in North-East China agricultural sector: A DEA approach. Agricultural Economics-Czech61(11), 522-532.

doi: 10.17221/233/2014-AGRIECON.

[12]. Malmquist, S.(1953).Index numbers and indifference surfaces. Trabajos de Estadistica4(2),209242.doi: 10.1007/BF03006863.

[13]. Mohan, G., \&Matsuda, H. (2013). Regional level total factor productivity growth in Ghana agriculture. Journal of Economics and Sustainable Development4(5), 195-206.

[14]. NRC.(1979). Panel to review productivity statistics: Measurement and interpretation of productivity. National Academy of Sciences, National Research Council, Washington DC, USA.

[15]. OAE. (2016). Agricultural statistics of Thailand in 2015. Ministry of Agriculture and Cooperatives, Office of Agricultural Economics, Bangkok, Thailand.

[16]. Odeck, J. (2009). Statistical precision of the DEA and Malmquist indices: A bootstrap application to Norwegian grain producers. Omega37(5), 1007-1017.

doi: 10.1016/j.omega.2008.11.003.

[17]. Shephard,R.W.(1953).Cost and Production Functions. New Jersey: Princeton University Press. [18]. Su, G.H. (2010). Technical efficiency of corn production in main producing region in China based on DEA-Tobit. Asian Agricultural Research2(12), 5-7, 11.

[19]. Zhou, L., \&Zhang, H.P. (2013).Productivity growth in China's agriculture during 1985-2010. Journal of Integrative Agriculture 12(10), 1896-1904.doi: 10.1016/s2095-3119(13)60598-5. 
Table1. The overview of previous studies on the productivity change of maize and other agricultural productions

\begin{tabular}{|c|c|c|c|}
\hline Authors & $\begin{array}{l}\text { Period } \\
\text { of study }\end{array}$ & $\begin{array}{c}\text { Commodities and } \\
\text { countries }\end{array}$ & Empirical results \\
\hline$[18]$ & $\begin{array}{l}1998 \text { to } \\
2008\end{array}$ & $\begin{array}{l}\text { Corn production } \\
\text { in China }\end{array}$ & $\begin{array}{l}\text { The findings indicated that two provinces as Hubei } \\
\text { and Sichuan performed the best progress of the } \\
\text { total factor productivity change at } 9.6 \% \text {. }\end{array}$ \\
\hline [8] & $\begin{array}{l}1971 \text { to } \\
2010\end{array}$ & $\begin{array}{l}\text { Maize production } \\
\text { in Nigeria }\end{array}$ & $\begin{array}{l}\text { The empirical results revealed that the average of } \\
\text { total factor productivity change in the four decade } \\
\text { year periods was } 1.004 \text {, implying that its growth } \\
\text { showed at } 0.4 \% \text {. During the year periods } 1986 \text { to } \\
1990,1991 \text { to } 1995 \text { and } 2006 \text { to } 2010 \text { illustrated } \\
\text { that the total factor productivity change had the } \\
\text { increasing trends with } 3.7,35.7 \text {, and } 33.4 \% \text {, } \\
\text { respectivelv. }\end{array}$ \\
\hline [5] & $\begin{array}{l}1987 \text { to } \\
2002\end{array}$ & Belgium & $\begin{array}{l}\text { The total factor productivity change calculation } \\
\text { presented that it had a growth rate trend of } 17.0 \% \\
\text { over the } 16 \text { year periods. }\end{array}$ \\
\hline [16] & $\begin{array}{c}1987 \text { to } \\
1997\end{array}$ & Eastern Norway & $\begin{array}{l}\text { The results demonstrated that the average } \\
\text { productivity had a } 38.0 \% \text { in terms of progression } \\
\text { in the study period. The obtaining of it assessed } \\
\text { from the main findings of the technical change. }\end{array}$ \\
\hline [10] & $\begin{array}{l}2001 \text { to } \\
2007\end{array}$ & $\begin{array}{l}\text { Dairy farms in } \\
\text { Hungary and } \\
\text { France }\end{array}$ & $\begin{array}{l}\text { The study was found that the total factor } \\
\text { productivity change of French dairy farm } \\
\text { decreased about } 0.07 \% \text {; while, Hungarian dairy } \\
\text { farm had the increasing of the total factor } \\
\text { productivity change at } 2.0 \% \text {. }\end{array}$ \\
\hline [13] & $\begin{array}{l}2000 \text { to } \\
2009\end{array}$ & $\begin{array}{l}\text { Major principle } \\
\text { crop in Ghana }\end{array}$ & $\begin{array}{l}\text { The major findings examined that the Northern is } \\
\text { ranked no. } 1 \text { based on the total factor productivity } \\
\text { change among } 10 \text { regions in Ghana, followed by } \\
\text { the Eastern and Upper West defined ranking no. } 2 \\
\text { and no.3, respectively. }\end{array}$ \\
\hline & & $\begin{array}{l}\text { Agriculture sector } \\
\text { in China }\end{array}$ & $\begin{array}{l}\text { The growth rate of China's agriculture in terms of } \\
\text { the total factor productivity change during the } \\
\text { study period was } 55.2 \% \text {. }\end{array}$ \\
\hline [19] & $\begin{array}{l}1985 \text { to } \\
2010\end{array}$ & $\begin{array}{l}\text { Agricultural } \\
\text { sector in North- }\end{array}$ & $\begin{array}{l}\text { The results indicated that the Malmquist index } \\
\text { analysis showed that the average productivity } \\
\text { progress around } 8.0 \% \text {. }\end{array}$ \\
\hline [11] & $\begin{array}{l}2000 \text { to } \\
2012\end{array}$ & East China & \\
\hline
\end{tabular}


Table 2. Description of variables used in Thai maize production

\begin{tabular}{|c|c|c|}
\hline Variables & Unit & Definition \\
\hline \multicolumn{3}{|l|}{ Outputs produced } \\
\hline Quantity of maize & ton & The total maize quantity of production. \\
\hline \multicolumn{3}{|l|}{ Inputs used } \\
\hline Planted area & hectare & $\begin{array}{l}\text { The total agricultural land that is used for } \\
\text { maize farming. }\end{array}$ \\
\hline Seed & ton & $\begin{array}{l}\text { The total number of maize seed sown in maize } \\
\text { arable land. }\end{array}$ \\
\hline Fertilizer & ton & $\begin{array}{l}\text { The total number of chemical fertilizer that is } \\
\text { used in maize production. }\end{array}$ \\
\hline Number of household & number & $\begin{array}{l}\text { The total number of household which operate } \\
\text { in maize production. }\end{array}$ \\
\hline Irrigated land & hectare & $\begin{array}{l}\text { The total amount of arable land under the } \\
\text { services of the Royal Irrigation Department } \\
\text { which highly supply water for increasing } \\
\text { agricultural crops yield, especially maize yield. }\end{array}$ \\
\hline
\end{tabular}

Table 3. Summary descriptive statistics for variables used of maize production in Thailand during the year 2008 to 2015

\begin{tabular}{llllll}
\hline Variables & Unit & Mean & Std. Dev & Min & Max \\
\hline Outputs produced & & & & & \\
\hline Quantity of maize & ton & $119,231.14$ & $161,586.60$ & 25.00 & $714,706.00$ \\
\hline Inputs used & & & & & \\
\hline Planted area & hectare & $29,426.21$ & $39,732.11$ & 6.40 & $163,959.36$ \\
Seed & ton & 598.10 & 808.19 & 0.72 & $4,254.79$ \\
Fertilizer & ton & $9,768.77$ & $14,139.62$ & 10.58 & $59,712.66$ \\
Number of household & number & $10,862.18$ & $12,703.85$ & 14.00 & $49,723.00$ \\
Irrigated land & hectare & $72,003.61$ & $55,436.22$ & 1664.96 & $297,935.68$ \\
& & & & & \\
\hline
\end{tabular}


Table 4. The Malmquist productivity index results for maize production in Thailand during the year 2008 to 2015

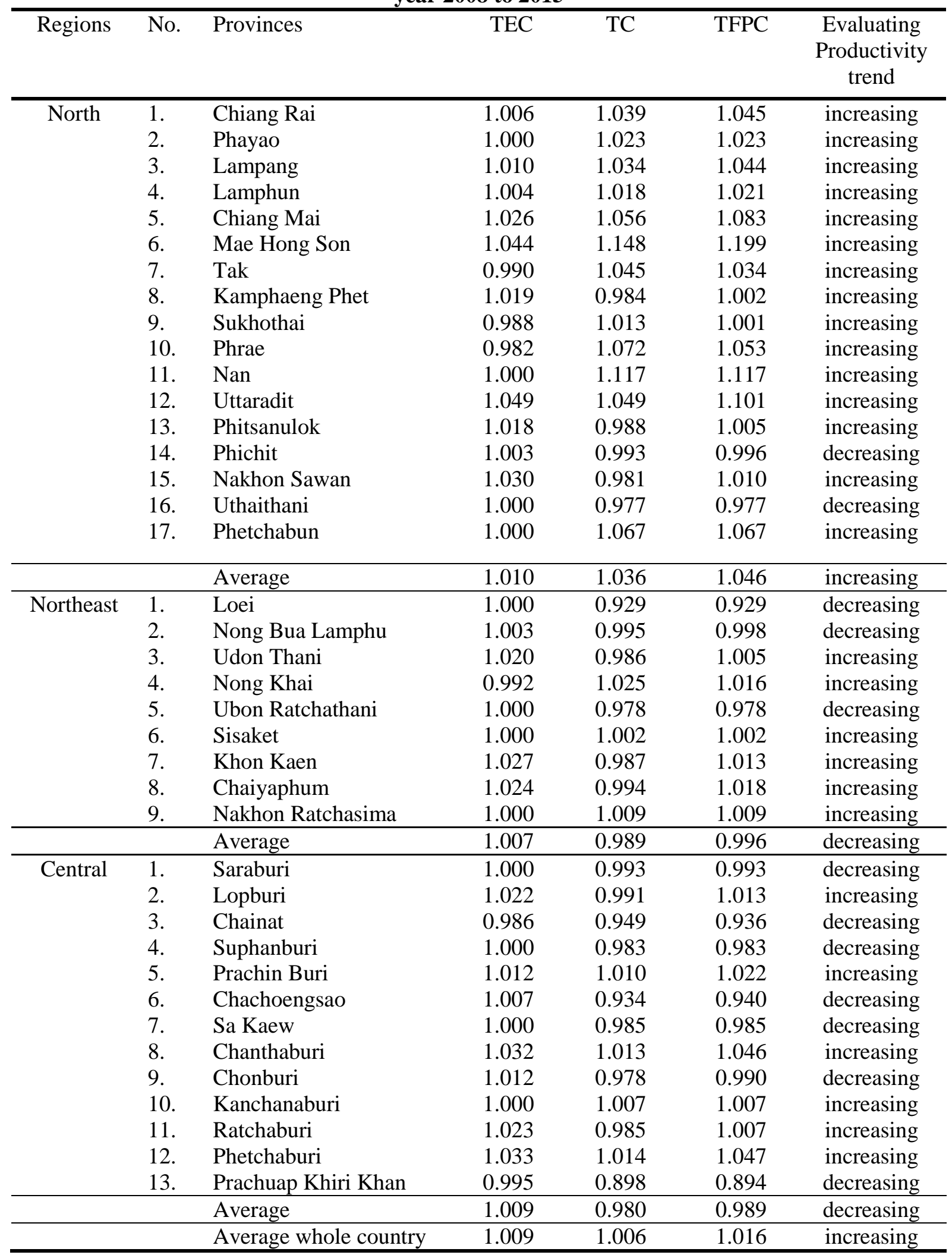


Malmquist productivity index $(\mathrm{MPI})=$ Technical efficiency change $(\mathrm{TEC}) \mathrm{x}$ Technological change (TC)

$$
\begin{aligned}
& M_{i}\left(X^{t+1}, y^{t+1}, X^{t}, y^{t}\right)=\left[\frac{D_{i}^{t+1}\left(X^{t+1}, y^{t+1}\right)}{D_{i}^{t}\left(X^{t}, y^{t}\right)}\right] \times\left[\frac{D_{i}^{t}\left(X^{t+1}, y^{t+1}\right)}{D_{i}^{t+1}\left(X^{t+1}, y^{t+1}\right)} \times \frac{D_{i}^{t}\left(X^{t}, y^{t}\right)}{D_{i}^{t+1}\left(X^{t}, y^{t}\right)}\right]^{\frac{1}{2}} \\
& M_{i}\left(X^{t+1}, y^{t+1}, X^{t}, y^{t}\right)=\left[\frac{D_{i}^{t}\left(X^{t+1}, y^{t+1}\right)}{D_{i}^{t}\left(X^{t}, y^{t}\right)} \times \frac{D_{i}^{t+1}\left(X^{t+1}, y^{t+1}\right)}{D_{i}^{t+1}\left(X^{t}, y^{t}\right)}\right]^{\frac{1}{2}}
\end{aligned}
$$

